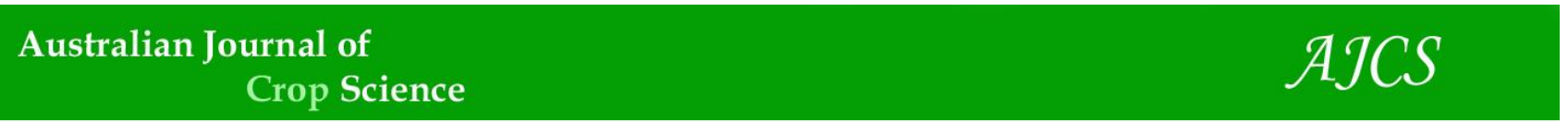

AJCS 14(05):810-815 (2020)

ISSN:1835-2707

\title{
Cotton is a promising crop for soil sustainability
}

\author{
Emanoel Costa Alves ${ }^{1}$, Mayara Andrade Souza ${ }^{2 *}$, Alberício Pereira Andrade ${ }^{3}$, Nair Helena de Castro \\ Arriel ${ }^{4}$, Fábio Aquino Albuquerque ${ }^{4}$ Riselane Lucena de Alcântara Bruno ${ }^{5}$
}

\author{
${ }^{1}$ Federal University of Lavras, Postgraduate Program in Entomology, Lavras, MG 37200-900, Brazil \\ ${ }^{2}$ Center University Cesmac, Postgraduate Program Environmental Systems Analysis, Maceió, AL 57 051-160, Brazil \\ ${ }^{3}$ Federal University Rural of Pernambuco, Department of Animal Production, Garanhuns, PE, Brazil \\ ${ }^{4}$ Embrapa Cotton, Campina Grande, PB 58 428-095, Brazil \\ ${ }^{5}$ Federal University of Paraiba, Postgraduate Program in agronomy, Areia, PB 58397-000, Brazil
}

*Corresponding author: mayarandrade@hotmail.com

Abstract

The coloured cotton crop is the best agroecological alternatives for farmers in semi-arid of Northeasthern region. Cultivation of BRS Verde cotton has been a success on productivity in this region. The practice of monoculture in cotton crop has caused loss of soil quality over the years. The organisms present in the soil are sensitive to changes of land use and management. They are excellent environmental bio indicators, representing important tool to evaluate impacts on ecosystems. In this context, the aim of this research was to evaluate the abundance and diversity of edaphic macrofauna under different management systems in the cotton crop. The design was a randomized complete block design with four replicates with five treatments in 5 collection seasons. The plots consisted of 8 lines spaced $1.0 \times 0.30 \mathrm{~m}$ for all crops. Three PROVID traps were distributed to capture soil organisms, totally 12 samples/treatments. We identified taxonomic groups, density of organisms, ecological indexes of diversity and wealth of groups. In view of the results, we concluded that the cotton + maize consortium favoured increase of individual's abundance and richness of faunistic groups. This cotton + maize consortium showed to be a promising alternative for better management and sustainability of the system. We also showed that soil macrofauna is a good indicator of soil quality in different cotton growing systems.

Keyword: soil organisms; biological indicator; soil conservation; agricultural practices; nutrient cycling.

\section{Introduction}

In the agricultural scenario, the cotton culture presents great economic importance, being cultivated in more than 60 countries. Brazil is the third largest exporter, the first in terms of dry land productivity and the fifth largest consumer (ABRAPA, 2015). It currently has a promising domestic market because it has one of the most important fibbers in the world.

Cotton cultivation is of great socioeconomic relevance for the Northeast of Brazil, especially for the semi-arid region. Particularly the State of Paraíba has favourable conditions for cultivation. However, for decades the use of monoculture caused inappropriate forms of soil management, pest incidence and long periods of drought, resulting in low crop productivity.

The cultivation of cotton in a monoculture system for consecutive years promotes innumerable modifications in the soil, leading to modifications of the physical, chemical and biological properties, affecting the development of plants with reflexes on the soil biota.

The current stock production system is totally dependent on external inputs and with high production cost, becoming restricted to a small portion of cotton farmers. In the semiarid region of Northeastern Brazil, the cultivation of agroecological coloured cotton has become one of the best income alternatives for cotton farmers, as it adds value to production, pursues environmental, economic and social sustainability. In addition, the farms are mainly occupied by crops in intercropping systems and the workforce is familiar with cultivation of cotton in this way (Queiroga et al., 2008; Beltrão et al., 2009).

The BRS VERDE cotton cultivar was released and became available by Embrapa cotton. This cultivar produces green fibre. This fibre may partially fade when boll is exposed to sunlight. This fibre may be preferable for spinning thick yarns and jeans compared to other crafts. It has aptitude for sustainable cultivation in the Northeastern semi-arid region, showing successful productivity, with a response of $3,000 \mathrm{~kg}$ $\mathrm{ha}^{-1}$ in winter conditions. The same production level may need approximately $70 \%$ to $80 \%$ of costs employed with well-managed labour and better cultural treatments. In these areas cotton production are owned by families. Thus, cotton planting is important for the family (Cartaxo et al., 2008; Queiroga et al., 2008).

Crop intercropping is known as the growth of two or more species in the same area over a period of time (Rezende et al. 2006). The application of this practice by cotton farmers, according to Beltrão et al., (2010) may improve land use and the possibility of total loss of production.

In order to strengthen this productive chain, family farmers have been doing agriculture on an agro ecological basis, 
seeking to add value to production and provide ecological, social and economic benefits (Americo et al., 2013; Beltrão et al., 2009). In this sense, intercropping has become a common practice among small farmers, making land use more efficient, and promoting nutrient recycling, increasing soil fertility and soil biota, favouring sustainability (Rochaet al., 2012).

Soil serves as a habitat for a diversity of organisms, which can be classified according to their morphological and functional aspects. The edaphic macrofauna plays an important role in fertility, with participation in the biogeochemical cycles, by assisting release of elements and contributing to the structural development of the soil (Almeida et al., 2015).

The diversity of these organisms in the soil, richness and uniformity of distribution in the group, indirectly demonstrate the environmental conditions of the area, as to the degree of conservation. In this study, the most abundant species were found to be diverse in the groups (Jacobs et al., 2007).

Many researches have been conducted on the effect and use of conservation practices, such as green manuring, no-tillage and agro forestry systems on soil biota (Terry et al., 2015; Tacca et al., 2017; Aalmeida et al., 2017). However, studies demonstrating the importance of macrofauna as a bioindicator of soil quality in intercropping systems are still scarce (Almeida et al., 2008; Silva et al., 2013; Brito et al., 2014) and even scarce in cotton crops.

Due to the importance of these organisms to maintain sustainability, it is necessary to study the dynamics of the communities of soil organisms in different cropping systems. In this context, the objective of this study was to evaluate the abundance and diversity of soil macrofauna organisms under different management systems in the cotton crop.

\section{Results and discussion}

\section{Abundance of groups}

The abundance of the faunal groups in the collection periods revealed a difference in soil macrofauna individuals. A total of 10,424 individuals were recorded from 50 to 110 DAS, distributed in 12 groups. The population of Hymenoptera was predominant compared to other groups. A high number or density of individuals in Hymenoptera group was also verified by Correa et al. (2009) and Portilho et al. (2008) in different organic management systems of of coffee production enriched with other species, when compared to the conventional system. Portilho et al. (2011) mentioned that the Hymenoptera group was the most representative in all levels of cane straw. Pasqualin et al. (2012) observed the predominance of this group in cane areas, compared to the forest area. Silva et al. (2012) reported that ants may occupy several positions in the trophic chain, causing various effects on the environment, such as under-ground colonies. Among the groups, Orthoptera, Coleoptera and Araneae stand out, with $98.3 \%$ of the total and the remaining $1.7 \%$. Faunistic groups that appear in smaller number is probably restricted to more favourable environments, with great importance in the process of organic matter decomposition.

The abundance of individuals was influenced by the soil and climatic conditions in the collection periods, management systems and soil cover, where the cotton + maize consortium (T2) and maize monoculture (T4) had larger populations (Fig 2 and 3 A and B ). In contrast to modern farming systems, the consortium system deserves attention due to the wealth of ecological interactions, cultural arrangement and management in the field. The abundance of individuals had direct proportional relation to water content of the soil and inversely proportional to the temperature (Fig $3 \mathrm{~A}$ and $\mathrm{B}$ ). There was a decrease in the water content due to the low rainfall with consequent increase of the soil temperature, contributing to the reduction of organisms.

\section{Diversity index}

The Shannon diversity index reflects a larger population of individuals from a particular group or groups at the expense of others (Begon et al., 2006; Souza et al., 2016), and soil and climatic conditions show to be definitive for this (Fig. 3A and B). Similar behaviour of treatments was observed for Pielou uniformity index. However, a difference was observed at 50 and 65 DAS (Table 1), whereas the area of anthropoid forest (T5) showed the highest values, indicating a greater balance in individual's composition of the macrofauna. It was verified that the richness of faunistic groups differed up to 95 DAS, with superiority for the area consorted with cotton + maize (T2) (Table 1). The agro consortium systems include different crops, in which yield can exceed the single crop. The increase may be related to the complementary nature of characteristics in studied populations (Gliessman, 2000).

Although T2 provided greater abundance, it suffered a greater reduction in the number of individuals to detriment the edaphoclimatic conditions (Figure 3 ), but maintained its wealth (Table 1). This shows the importance of the cotton + maize consortium and the behaviour of edaphic fauna, providing an adequate microclimate and / or greater availability of food, among other factors. Araújo (2010) verified that at the end of the rainy season, after the leaf fall, the macrofauna taxonomic groups tend to increase due to food distribution. Two-way clustering revealed variability of efficiency between the adopted soil management systems, with formation of two groups, one containing the T1, T3, T4 and T5 treatments and another containing formally T2 'treatment (Figure 4). The variables were distributed in two dimensions that explain $93.98 \%$ of the data matrix variance $(85.30 \%$, dimension 1 and $8.68 \%$, for 2$)$. Throughout CP1 (main axis), the T2 treatment is arranged in the most extreme right portion (positive value) and the T3, T4 and T5 treatments in the median portion, while the T1 treatment is in the left portion (negative value), demonstrating separation between treatments. The distinction between these two groups shows that there is population diversity between and within them. Although it belongs to the same group, there is a clear distance between $\mathrm{T} 1$ and the other components of group 1, which is even more evident for $\mathrm{T} 2$ component of group 2 .

\section{Materials and methods}

\section{Experimental area}

The experiment was conducted at the Experimental Station of the Agricultural Company of Paraíba (EMEPA), municipality of Alagoinha, mesoregion of Agreste Paraibano, microregion of Guarabira, State of Paraíba. The climate of the region is characterized, according to Koppen, as As', hot and humid, with average air temperatures around 25 ㅇ (CLIMATEMPO, 2016). 
Table 1. Shannon diversity indexes and Pielou uniformity and richness of faunistic groups of soil macrofauna under different cropping systems and soil coverage's in the post-sowing period.

\begin{tabular}{|c|c|c|c|c|c|}
\hline \multirow{2}{*}{$\begin{array}{l}\text { Systems of } \\
\text { cultivation }\end{array}$} & \multicolumn{5}{|c|}{ Evaluation Periods (DAS) } \\
\hline & 50 & 65 & 80 & 95 & 110 \\
\hline \multicolumn{6}{|c|}{-ー-ー-ー-- Shannon diversity index $(H)---------$} \\
\hline $\mathrm{T} 1$ & $0.605 \mathrm{aA}$ & $0.615 \mathrm{aA}$ & $0.608 \mathrm{aA}$ & $0.613 \mathrm{aA}$ & $0.610 \mathrm{aA}$ \\
\hline $\mathrm{T} 2$ & $0.623 \mathrm{aA}$ & $0.620 \mathrm{aA}$ & $0.610 \mathrm{aA}$ & $0.615 \mathrm{aA}$ & $0.608 \mathrm{aA}$ \\
\hline T3 & $0.608 \mathrm{aA}$ & $0.613 \mathrm{aA}$ & $0.610 \mathrm{aA}$ & $0.610 \mathrm{aA}$ & $0.610 \mathrm{aA}$ \\
\hline T4 & $0.605 \mathrm{aA}$ & $0.780 \mathrm{aA}$ & $0.628 \mathrm{aA}$ & $0.605 \mathrm{aA}$ & $0.608 \mathrm{aA}$ \\
\hline T5 & $0.850 \mathrm{aA}$ & $0.623 \mathrm{aA}$ & $0.623 a \mathrm{~A}$ & $0.605 \mathrm{aA}$ & $0.613 \mathrm{aA}$ \\
\hline $\mathrm{CV}(\%)$ & 32.27 & & & & \\
\hline \multicolumn{6}{|c|}{--ー-----Pielou uniformity index $(e)-------$} \\
\hline $\mathrm{T} 1$ & $0.120 \mathrm{aAB}$ & $0.153 a \mathrm{~A}$ & $0.150 \mathrm{aA}$ & $0.150 \mathrm{aA}$ & $0.123 a \mathrm{~A}$ \\
\hline $\mathrm{T} 2$ & $0.068 \mathrm{aB}$ & $0.073 a \mathrm{a}$ & $0.088 \mathrm{aA}$ & $0.088 \mathrm{aA}$ & $0.088 \mathrm{aA}$ \\
\hline T3 & $0.075 \mathrm{aAB}$ & $0.088 \mathrm{aAB}$ & $0.155 \mathrm{aA}$ & $0.075 \mathrm{aA}$ & $0.120 \mathrm{aA}$ \\
\hline T4 & $0.085 \mathrm{aAB}$ & $0.130 \mathrm{aAB}$ & $0.125 a \mathrm{~A}$ & $0.088 \mathrm{aA}$ & $0.102 \mathrm{aA}$ \\
\hline T5 & $0.140 \mathrm{aA}$ & $0.155 \mathrm{aA}$ & $0.153 a A$ & $0.123 a A$ & $0.123 a A$ \\
\hline CV (\%) & & & 30.34 & & \\
\hline \multicolumn{6}{|c|}{-- Wealth } \\
\hline $\mathrm{T} 1$ & $4.25 \mathrm{aB}$ & $3.75 \mathrm{aB}$ & $4.00 \mathrm{aB}$ & $3.75 \mathrm{aB}$ & $3.5 \mathrm{aA}$ \\
\hline $\mathrm{T} 2$ & $7.00 \mathrm{aA}$ & $6.50 \mathrm{aA}$ & $6.25 \mathrm{aA}$ & $6.00 \mathrm{aA}$ & $5.25 \mathrm{aA}$ \\
\hline T3 & $5.50 \mathrm{aAB}$ & $4.25 \mathrm{aB}$ & $4.25 \mathrm{aAB}$ & $4.50 \mathrm{aAB}$ & $3.75 \mathrm{aA}$ \\
\hline T4 & $6.00 \mathrm{aAB}$ & $5.00 \mathrm{aAB}$ & $4.75 a \mathrm{AB}$ & $5.25 a \mathrm{AB}$ & $5.00 \mathrm{aA}$ \\
\hline T5 & 5.00aAB & $3.75 \mathrm{aB}$ & $4.75 \mathrm{aB}$ & $5.25 \mathrm{aAB}$ & $5.00 \mathrm{aA}$ \\
\hline CV (\%) & & & 22.7 & & \\
\hline
\end{tabular}

*Means followed by the same lowercase letter, in the line, and upper case, in the column, do not differ from each other, by Tukey test, at 5\% probability. T1: naked only; T2: cotton + corn; T3: single cotton; T4: single corn; T5: Anthropized forest.

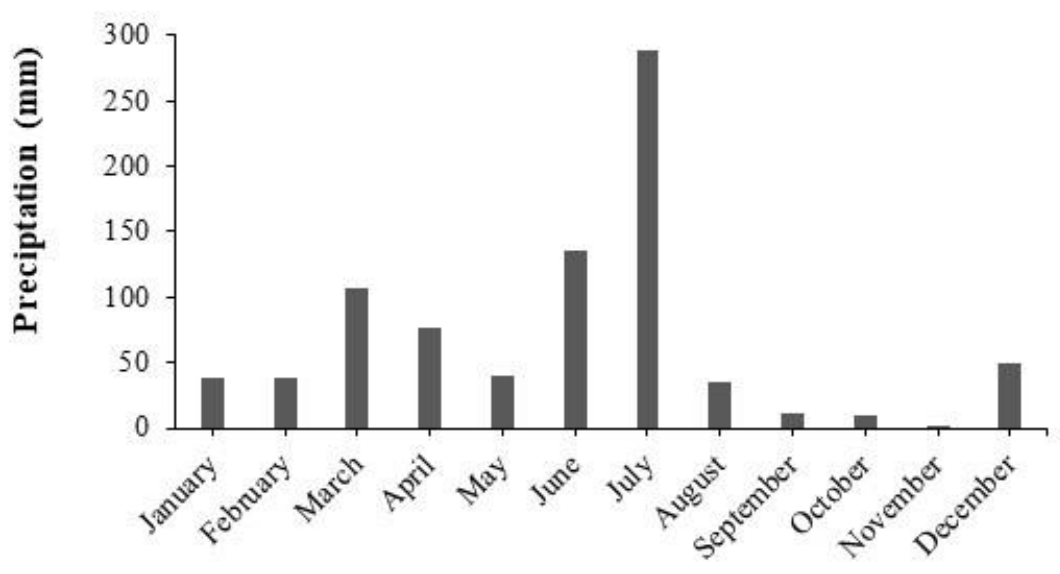

Months

Fig 1. Rainfall in the experimental area in the year 2015.

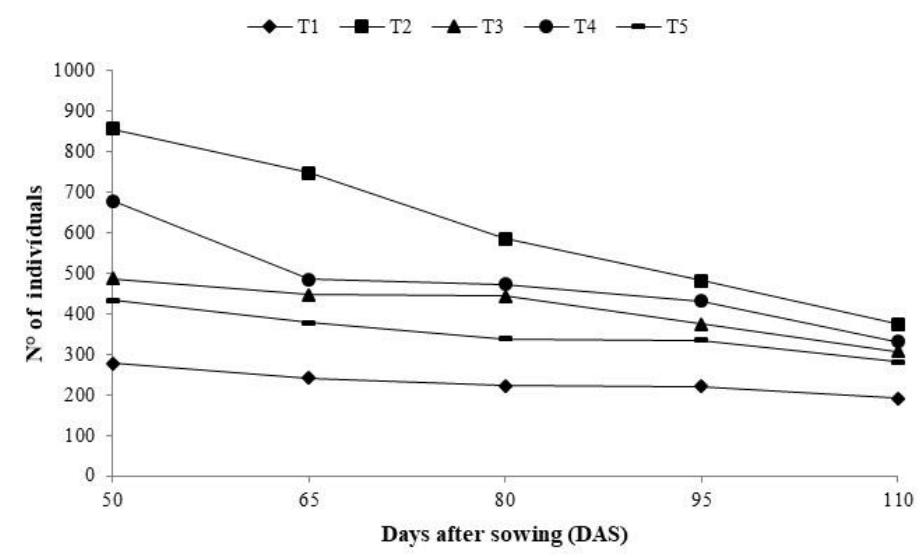

Fig 2. Abundance of individuals in the treatments evaluated in the collection periods. T1: naked only; T2: cotton + corn; T3: single cotton; T4: single corn; T5: Anthropized forest. 


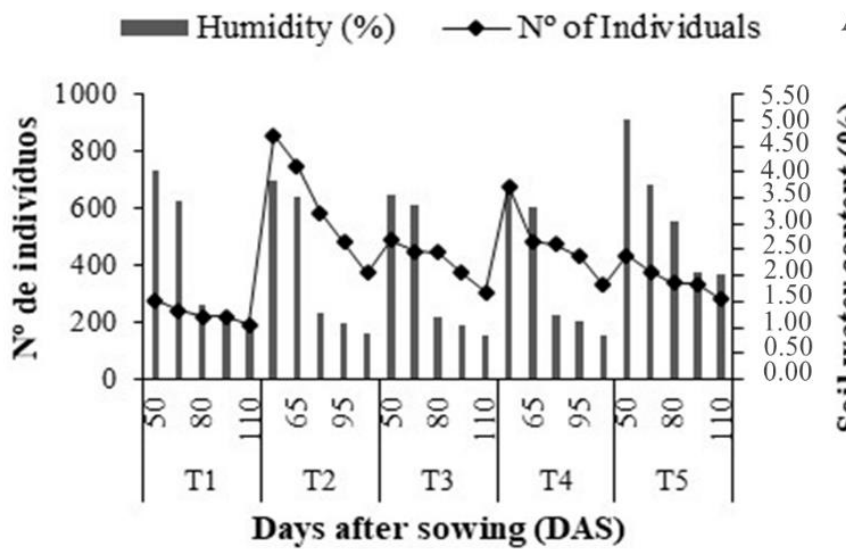

A

Temperature $\left({ }^{\circ} \mathrm{C}\right) \longrightarrow \mathrm{N}^{\circ}$ de individuos

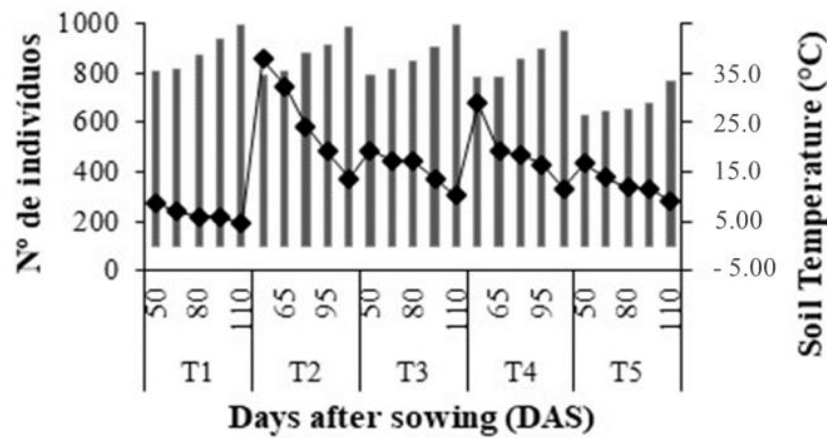

Fig 3. Abundance of individuals in treatments evaluated as a function of water content $(A)$ and soil temperature (B) in the collection periods. T1: naked only; T2: cotton + corn; T3: single cotton; T4: single corn; T5: Anthropized forest.
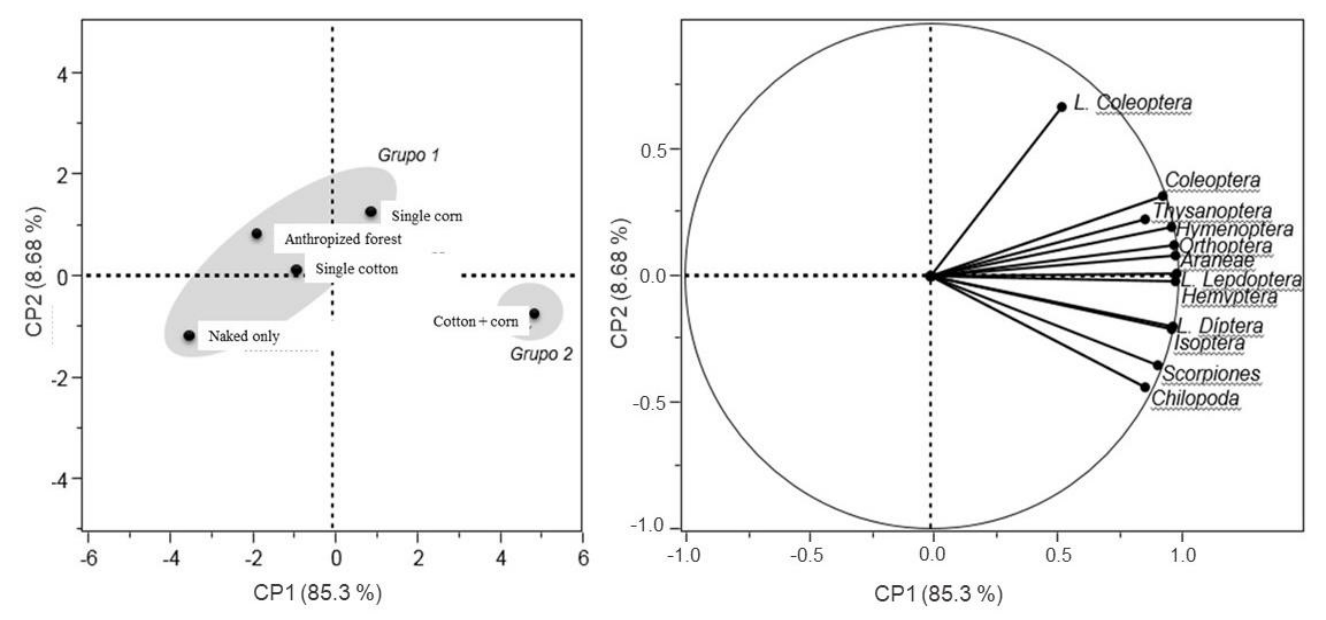

Fig 4. Principal component analysis for the faunistic groups of the edaphic macrofauna under different cropping systems and soil cover.

The average annual rainfall over the last ten years was on the order of $1170 \mathrm{~mm}$ with rainfall concentrating on the autumn-winter seasons (AESA, 2015). The monthly rainfall distributions during the experiment period (June to October 2015) are presented in Fig 1.

The soil of the experimental area is characterized as a CLASSIC CHRONIC LUVISSOL (EMBRAPA, 2013), which has been exploited in recent years with annual crops, such as maize, which was the last crop used before implantation. For the preparation of the area, two ploughing and harrowing were done, followed by the marking of experimental plots for implantation of the treatments.

\section{Experimental design and collections}

The experimental design was a randomized block design with four replications in a $5 \times 5$ factorial scheme, with five collection times $(50,65,80,95$ and 110 days after sowing) and five treatments: bare soil (T1), consortium of the cotton cultivar BRS Green (Gossypium hirsutum L.) with maize (Zea mays L.) (T2), single cotton cultivation (T3), single corn cultivation (T4) and anthropoid forest area (T5).
The size plots of $5.0 \times 7.0 \mathrm{~m}$ were composed of 8 lines with spacing of $1.0 \times 0.30 \mathrm{~m}$ for cotton and single maize crops. In the plots with consorts, these obtained 4 central lines of the culture consorted and 2 lines of cotton. Among the plots we distributed PROVID traps, made with PET bottles of $2 \mathrm{~L}$, containing four orifices of $2 \times 2 \mathrm{~cm}$ at the height of $10 \mathrm{~cm}$ of the base, totally 12 samples/treatments, located in the centre of the central line and the lateral lines for the consorts and single treatments. In the bare soil plots, the traps were distributed in the central line of the plot. In the anthropoid forest area 12 traps were placed randomly with at least $2 \mathrm{~m}$ distant from one another.

The first collection was performed on the 50th day after sowing (DAS) when the crops were in full development, with subsequent biweekly collections up to 110 days (end of cycle). In each trap, $200 \mathrm{~mL}$ of $5 \%$ detergent solution and 5 drops of Formol P.A. were added, which remained in the field for 96 hours (Araújo, 2010).

After camp stay, organism traps were collected, washed and passed through $0.25 \mathrm{~mm}$ mesh sieves and stored in a $70 \%$ alcohol solution. All organisms of the macrofauna ( $>2 \mathrm{~mm}$ ) were counted and identified with magnifying glass and tweezers, according to the order of the taxonomic groups, 
which were evaluated quantitatively through the total number of organisms (abundance) and qualitatively through diversity, richness and uniformity/equitability.

\section{Statistical analysis}

For the diversity the Shannon Index $(\mathrm{H})$ was used through the equation: $\mathrm{H}=-\Sigma$ pi.logpi, where: $\mathrm{pi}=\mathrm{ni} / \mathrm{N} ; \mathrm{ni}=$ density of each order; $N=\Sigma$ of the density of all orders. For the richness of the taxonomic groups we used the number of groups present in the treatment. For equitability, the Pielou Index (e), defined by: $\mathrm{e}=\mathrm{H} / \operatorname{logS}$, where: $\mathrm{H}=$ Shannon diversity index; $\mathrm{S}=$ number of species or groups were used (Odum, 1993; Begon et al., 1996).

The data were submitted to analysis of variance (ANOVA) with the means compared by the Tukey's test at $5 \%$ of probability, using ASSISTAT software (Silva, 2011) and the multivariate analysis for the main components based on the observed correlations between the orders in response to different management systems. Two-way clustering was performed for the dependent and independent variables based on the cubic criterion for clustering. The software JMP ${ }^{\circledR}$ 10.0.0 (SAS INSTITUTE INC, 2012) was used.

\section{Conclusions}

The cotton + maize consortium production system favours the increase the abundance of individuals and wealth of faunistic groups. The cotton intercropping consortium represents a promising alternative for better management and sustainability of the system. Soil macrofauna is a good indicator of soil quality in different cotton growing systems. The level of anthropization of natural vegetation can compromise the abundance, diversity, uniformity and richness of faunistic groups.

\section{Acknowledgments}

Thanks to the Postgaduate Program in Agronomy of the Federal University of Paraíba, Areia, PB for the support and by EMBRAPA - CNPA / CAPES, for granting scholarships to authors.

\section{References}

ABRAPA, O Algodão no Brasil. Disponível em: $<$ http://www.abrapa.com.br/estatisticas/Paginas/Algodao -no-Brasil.aspx>. Acessado em: 01 set. 2015.

AESA. Pluviometria. 2015. Disponível em: <http://site2.aesa.pb.gov.br/aesa/monitoramentoPluviom etria.do?metodo=listarAnosChuvasAnuais $>$. Acesso em: 10 set. 2015.

Almeida MVR, Oliveira TS, Bezerra AME (2009) Biodiversidade em sistemas agroecológicos no município de Choró, CE, Brasil. Ciência Rural. 39: 1080-1087.

Almeida MAX, Souto JS, Andrade AP (2015) Sazonalidade da macrofauna edáfica do Curimataú da Paraíba, Brasil. Rev Ambiência. 11: 393-407.

Almeida HS, Silva RF, Grolli AL, Scheid DL (2017) Ocorrência e diversidade da fauna edáfica sob diferentes sistemas de uso do solo. Rev Bras Tecn Agrop.1:15-23.

Altieri MA (1999) The ecological role of biodiversity in agroecosystems Agric Ecosys Environ. 74:19-31.
Americo GHP, Americo JHP, Furlani Júnior E (2013) Algodão orgânico: possibilidade sustentável no setor agrícola. IX Fórum Ambiental da Alta Paulista. 9:.1-7.

Araújo WBM, Alencar RD, Mendonça V, Medeiros EV, Andrade RC, Araújo RR (2010) Esterco caprino na composição de substrato para formação de mudas de mamoeiro. Rev Cienci Agrotecs.34: 68-73.

Beltrão NEM, Silva CAD, Bastos CS, Suinaga FA, Arriel NHC, Ramalho FS (2009) Algodão agroecológico: opção de agronegócio para o semiárido do Brasil. Campina Grande, PB: Embrapa Algodão, 62 p. (Embrapa Algodão. Documentos, 222).

Beltrão NEM, Vale LS, Marques LF, Cardoso GD, Souto JS (2010) Consórcio mamona e amendoim: opção para agricultura familiar. Rev Verd. 5: 222-227.

Begon M, Harper JL, Townsend CR. (ed) (1996) Ecology: individuals, populations and communities. 3 ed Blackwell Science, Oxfor. 1068p.

Brito MF, Tsuujifushi BP, Gomes SS, Silva RF, Otsubo AA, Mercante FM (2014) Atributos microbiológicos e fauna invertebrada epigeica do solo em cultivo de milho consorciado com leguminosas. Cadernos Agroecologia. 9: 1-12.

Cartaxo VW, Guimãres FM, Soares JJ, Beltrão NEM (2008) Potencialidades da produção de algodão pela agricultura familiar do Nordeste. Campina Grande, PB: Embrapa Algodão, 28 p. (Embrapa Algodão. Documentos, 202).

CLIMATEMPO (2016) O céu fala, a gente entende. Disponível em:

$<$ http://www.climatempoconsultoria.com.br/historico-dedados meteorologicos/?utm_campaign=Historico de dados\&utm_source=Pagina de prev\&utm_medium=Link abaixo prev\&utm_content=Climatempo $>$. Acesso em: 12 ago. 2016.

Correia KG, Araújo KD, Azevedo LG, Barbosa EA, Souto JS, Santos T N A S (2009) Macrofauna edáfica em três diferentes ambientes na região do agreste Paraibano, Brasil. Eng Ambien. 6: 206-213.

Embrapa (2013) Sistema Brasileiro de Classificação de Solos. Brasília: Embrapa-Solo, Rio de Janeiro. 353p.

Giracca EMN, Antoniolli ZI, Eltz FLF, Benedetti E, Lasta E, Venturini SF, Venturini EF, Benedetti T (2003) Levantamento da meso e macrofauna do solo na microbacia do Arroio Lino, Agudo/RS. Rev Bras Agroci. 9: 257-261.

Gliessman SR. (2000) Agroecologia: processos ecológicos em agricultura sustentável. Porto Alegre: UFRGS. 653p.

Jacob LE, Eltz FLF, Rocha MR, Guth PL, Hilckman C (2007) Diversidade da fauna edáfica em campo nativo, cultura de cobertura milho + feijão de porco sob plantio direto e solo descoberto. Trabalho apresentado em XXXI Congresso Brasileiro de Ciências do Solo, Gramado 2007.

Lima FS, Beltrão NEM, Oliveira FA, Pereira WE, Sousa CS (2008) Épocas relativas de plantio e adubação nitrogenada: índices agroeconômicos do algodoeiro consorciado com gergelim. Rev Cien Agron. 39:555-561.

Lourente ERP, Silva RF, Silva DA, Marchetii ME, Mercante FM (2007) Macrofauna edáfica e suas interações com atributos químicos e físicos do solo sob diferentes sistemas de manejo. Acta Sci Agron. 29:17-22.

Moço MKS, Gama-Rodrigues EF, Gama-Rodrigues AC, Correia MEF (2005) Caracterização da fauna edáfica em diferentes coberturas vegetais na região norte fluminense. Rev Bras Ci Solo. 29:555-564.

Odum EP (1993) Ecologia. Rio de Janeiro: Guanabara. 434p. 
Oliveira SEM, Andrade Junior AS, Ribeiro JL, Barros MA (2013) Coeficientes de cultura do algodão herbáceo e do feijão-caupi em sistemas monocultivo e consorciado. Rev Bras Agric Irrigada.7:191 - 200.

Pasqualin LA, Dionisio J A, Zawadneak MAC, Marçal CT (2012) Macrofauna edáfica em lavouras de cana-de-açúcar e mata no noroeste do Paraná - Brasil. Semina. 33: 7-18.

Portilho II, Silva RF, Mercante FM (2008). Macrofauna epigéica em diferentes sistemas de manejo de café orgânico em Mato Grosso do Sul. Rev Bras Agroecol. 3: 16.

Portilho IIR, Borges CD, Costa AR, Salton JC, Mercantes FM (2011). Resíduos da cultura da cana-de-açúcar e seus efeitos sobre a fauna invertebrada epigeica. Semina.32: 959-970.

Queiroga VP, Carvalho LP, Cardoso GD (2008) Cultivo do algodão colorido orgânico na Região Semi-Árida do Nordeste brasileiro. Campina Grande, PB: Embrapa Algodão, 49 p. (Embrapa Algodão. Documentos, 204).

Rocha HCR, Alvarenga CD, Giustolin TA, Blant RS, Souza MDC, Sarmento HGS, Barbosa MG (2012) Crescimento, produção de fitomassa e teor de óleo essencial de folhas de capim citronela (Cymbopogon nardus (L.) Rendle) em cultivo consorciado com algodoeiro colorido no semiárido mineiro. Rev Bras Plant Medicinais. 14:183-187.

SAS INSTITUTE (2012) SAS/STAT: user's Guide. Version 10.0.0. Cary: SAS Institute.

Silva MNB, Alves GS, Wanderley Júnior J. S. A (2009) Manejo cultural do algodoeiro agroecológico no Semiárido brasileiro. Campina Grande, PB: Embrapa Algodão, 10 p.
Silva RF, Corrassa GM, Bertollo GM, Santi AL, Steffen RB (2013) Fauna edáfica influenciada pelo uso de culturas e consórcios de cobertura do solo. Pesq Agropec Tropic. 43:130-137.

Silva FAZ (2015) Programa computacional ASSISTAT Assistência Estatística. Versão 7.7 beta. Campina Grande: UFCG, 2015

Silva GS, Oliveira RA, Silva MNB, Nascimento BLM, Bezerra MAF, Costa JS, Araujo LM (2013) Crescimento e produção de cultivares de algodão herbáceo consorciados no Cariri Cearense. Agropec Cient Semi-árido. 9:104-109.

Silva J, Juncksch I, Feres C, Tavares RC (2012) Fauna do solo em sistemas de manejo com café. J Biotech and Biodiver. 3:59-71.

Silva R.F, Aquino AM, Mercante FM, Guimarães MF (2006) Macrofauna invertebrada do solo sob diferentes sistemas de produção em Latossolo da região do Cerrado. Pesq Agropec Bras. 41:697-704.

Souto PC, Souto J L, Santos RV, Bakke IA, Sales FCV, Souza BV (2007) Decomposição da serapilheira e atividade microbiana em área de caatinga. Apresentado em XXXI Congresso brasileiro de ciência do solo, Gramado.

Souza JT, Farias AA, Ferreira RCC, Oliveira S J C, Cavalcante LF, Figueiredo LF, Correira FG (2016) Macrofauna edáfica em três ambientes diferentes na região do Cariri Paraibano, Brasil. Rev Scient Agrar Paranaensis. 15: 94-99.

Tacca D, Klein C, Preuss JF (2017) Artropodofauna do solo em um bosque de eucalipto e um remanescente de mata native no sul do Brasil. Rev Thema.14: 249-261. 